\title{
GIS Based Analysis of Agroclimate Land Suitability for Banana Plants in Bali Province, Indonesia
}

\author{
I Wayan Nuarsa ${ }^{1,2 *}$, I Nyoman Dibia ${ }^{1}$, Ketut Wikantika ${ }^{1,3,4,5}$, Deni Suwardhi, ${ }^{3,4}$ I Nyoman Rai',2 \\ 'Bali International Research Center for Banana (BIRCB), Udayana University, Bali, Indonesia \\ 2Department of Agroecotechnology, Faculty of Agriculture, Udayana University, Bali, Indonesia \\ ${ }^{3}$ Remote Sensing and GIS Research Group, Faculty of Earth Science and Technology, Institut Teknologi Bandung, Bandung, \\ Indonesia \\ ${ }^{4}$ Center for Remote Sensing, Institut Teknologi Bandung (CRS-ITB), Bandung, Indonesia \\ ${ }^{5}$ ForMIND Institute (Indonesian Young Researcher Forum), Bandung, Indonesia
}

\section{ARTICLE INFO}

\section{Article history:}

Received February 8, 2017

Received in revised form November 3, 2017

Accepted November 17, 2017

\section{KEYWORDS:}

banana,

land suitability,

GIS,

agriculture

\begin{abstract}
The need for bananas in Bali far exceeds the production. To obtain optimal production according to their genetic potential, the development of banana cultivation should be preceded by a land suitability evaluation study. This study aims to evaluate the land suitability based on agroecological parameters such as rainfall, altitude, dry month, slope, and considering current land use. The results showed that 257.467 ha or $46.16 \%$ of the area of Bali Province has the potential to be planted with bananas. Buleleng Regency has the widest area for the development of banana plants, followed by Karangasem, Tabanan, Jembrana and Bangli. Denpasar town has the smallest suitable area. Based on the observed agroclimate parameters, slope is the most severe limiting factor in banana cultivation, while rainfall, altitude, and dry months are not significant limiting factors. Recommended land use for the development of banana plants is garden, grass, rain-fed rice field, scrub, bare land, and moor.
\end{abstract}

\section{Introduction}

The rapidly growing world population places considerable pressure on increasingly scarce natural resources, spurring the need to develop more efficient and sustainable agricultural production systems to feed these growing populations (Kamkar et al. 2014). On the other hand, continuous utilization of agriculture land in past decades, regardless of land suitability has caused much more destruction than provide the resources (FAO 2007). Hence, proper evaluation based on agriculture land use planning is essential to solve this problem (Elsheik et al. 2010).

Crop-land suitability analysis is a prerequisite to achieving optimum utilization of the available land resources for sustainable agricultural production (Perveen et al. 2007). Land evaluation is a process of predicting land performance over time according to the specific types of use (Martin and Saha 2009; Sonneveld et al. 2010). Agriculture land suitability assessment is defined as the process of assessment of land performance when used for alternative kinds of agriculture (Mu 2006; He et al. 2011). The principle purpose of agriculture land suitability evaluation is

\footnotetext{
* Corresponding Author.

E-mail Address: nuarsa@unud.ac.id
}

to predict the potential and limitation of the land for crop production (Pan and Pan 2012).

Land-use suitability mapping and analysis is one of the most useful applications of Geographic Information Systems (GIS) for spatial planning and management (Malczewski 2004). Land-use suitability analysis is a multicriteria evaluation, which aims at identifying the most appropriate spatial pattern for future land uses according to specify requirements, preferences, or predictors of some activity. GIS serve the multicriteria evaluation function of suitability assessment well, providing the attribute values for each location and both the arithmetic and logical operators for combining attributes (Samanta et al. 2011).

Banana (Moses paradisiaca) is the most fruit commodity consumed in Indonesia, because about $45 \%$ of the consumption of fruits is banana. Indonesia is known as the $6^{\text {th }}$ banana producer in the world. Banana is the fourth most important food in developing country (FAO 2014). In Bali bananas are not only consumed as food but also as a means of praying. According to Central Bureau of Statistics (BPS 2016), the production of bananas in Bali is estimated at 190,235 tons per year, while the need for bananas far exceeds that number so that Bali is estimated to import bananas from outside Bali at around 100,000 tons per year. Bali Province has great potential for the 
development of banana plants. The objective of this study is to evaluate the land suitability of Bali Province based on agroclimate parameters using the GIS tools.

\section{Materials and Methods}

\subsection{Characteristics of Study Area}

The study area is located in the Bali Province of Indonesia centered at latitude $8^{\circ} 40^{\prime} 00^{\prime \prime} \mathrm{S}$ and longitude $115^{\circ} 19^{\prime} 00^{\prime \prime}$ E. Bali Province is divided into 8 regencies and 1 town with the total area is about 557,749 ha (Figure 1). Topographically, Bali Province is dominated by flat area in the south and north part of the island, and in the center part is dominated by hilly and mountainous areas. The average annual rainfall is around $1934 \mathrm{~mm}$. The highest average monthly rainfall was found in January about $345 \mathrm{~mm}$, and the lowest average was in August at $42 \mathrm{~mm}$. The warmest temperature of the year is in March, with an average temperature of $27.3^{\circ} \mathrm{C}$. July has the lowest average temperature in a year of $24.4^{\circ} \mathrm{C}$ (BPS 2016).

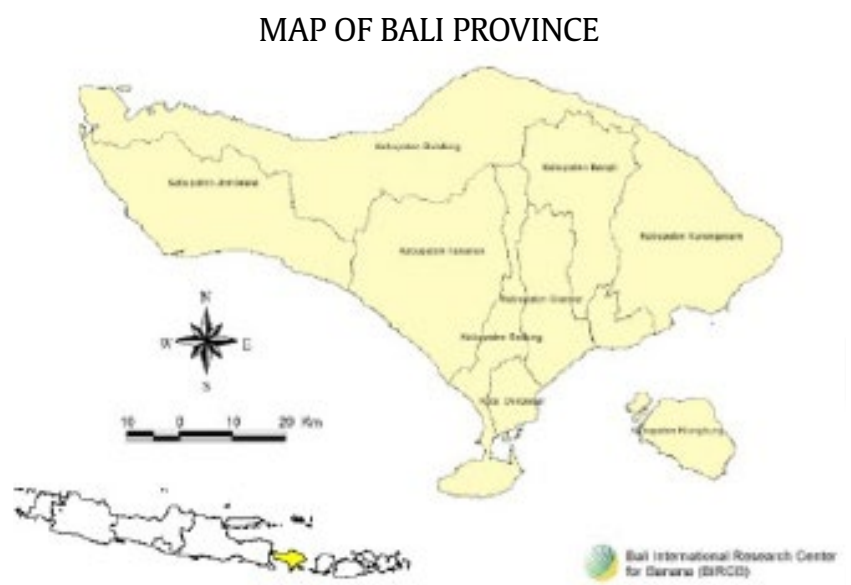

Figure 1. Research Location

\subsection{Materials and Equipment}

The materials used in this study consist of topographical map, slope map, isohyet map, land uses map, and rainfall data from 58 rain stations during 10 until 21 years. The equipment used for data processing is a set of computers with software for spatial and tabular data analysis.

\subsection{Agroclimate Land Suitability of Banana Plants}

Land suitability refers to the ability of a portion of land to tolerate the production of crops in a sustainable way. Agro-climatic and agro-ecological zoning schemes are standard tools for prioritizing agricultural research because they offer relevant and available information about target environments. The most obvious influences of weather on crop yield during the growing season are precipitation and temperature (Giardini et al. 1997).

\subsection{Retroviruses Production}

In this study, the land suitable analysis of banana plant focus on agroclimate parameters. Because rainfall, altitude and slope greatly affect the temperature and humidity, the agroclimate parameters used in this study consist of rainfall, altitude, dry month, and slope. The land suitability class is divided into 4 classes, that is Highly Suitable (S1), Moderately Suitable (S2), Marginally Suitable (S3), and Not Suitable. According to Djaenudin et al. (2003), the range of values of each class for fourth agroclimate parameters for banana plants are presented in Table 1.

Table 1 . The range value of agroclimate parameters for land suitability of banana plants

\begin{tabular}{lcccr}
\hline Agroclimate & $\begin{array}{l}\text { Highly } \\
\text { parameters } \\
\text { Suitable }\end{array}$ & $\begin{array}{l}\text { Moderately } \\
\text { Suitable } \\
\text { (S2) }\end{array}$ & $\begin{array}{l}\text { Marginally } \\
\text { Suitable } \\
\text { (S3) }\end{array}$ & $\begin{array}{l}\text { Not } \\
\text { Suitable } \\
(\mathrm{N})\end{array}$ \\
\hline $\begin{array}{l}\text { Altitude asl } \\
\text { (m) }\end{array}$ & $<1,200$ & $1,200-$ & $1,500-$ & $<2,000$ \\
$\begin{array}{l}\text { Rainfall } \\
\text { (mm/year) }\end{array}$ & $1,500-$ & 1,500 & 2,000 & \\
$\begin{array}{l}\text { Dry month } \\
\text { (month) }\end{array}$ & $0-500$ & 1,500 & $1,000-$ & $<1,000$ \\
Slope (\%) & $<8$ & $8-16$ & $16-40$ & $>60$ \\
\hline
\end{tabular}

\subsection{Support of Land Use for Banana Plants}

Based on Land Uses map from Geospatial Information Agency (BIG), land uses of Bali Province can be divided into 16 classes. However, not all for these land uses can be used for development of banana plants. Only 6 classes of land uses can be utilized, that is garden, grass, rain-fed rice field, scrub, bare land, and moor (Table 2).

Table 2. Supporting of exiting land uses for development of Banana Plants

\begin{tabular}{ll}
\hline Land Uses & Support for Banana Plant \\
\hline Water body & Does not support \\
Building & Does not support \\
Forest & Does not support \\
Garden & Support \\
Mangrove & Does not support \\
Sand & Does not support \\
Sand Beach & Does not support \\
Settlement & Does not support \\
Salting & Does not support \\
Grass & Support \\
Irrigated rice field & Does not support \\
Rain-fed rice field & Support \\
Scrub & Support \\
Ponds & Does not support \\
Bare land & Support \\
Moor & Support \\
\hline
\end{tabular}

\subsection{Area Development Analysis for Banana Plants}

Determination of area that can be used to develop Banana plants decided by two parameters, that is 
agroclimate suitability and exiting land uses support. Firstly, analysis was done by overlaying fourth agroclimate parameters map to produce agroclimate suitability map for banana plants. The land suitability level is decided by the highest limitation factor based on Table 1. The second step is overlaying the land suitable map for banana plants with the land uses that support for development of banana plants (Table 2). Finally, the suitable area for development of banana plants can be produced. Schematically, the procedure of the study is represented in Figure 2.

\section{Results}

\subsection{Individual Agroclimate Parameter of Banana Land Suitability}

Based on land suitable analysis for four agroclimate parameters, all parameters show high suitability for banana plans development. Altitude shows the highest suitability, around $93.31 \%$ are classified as a highly suitable, $4.73 \%$ area moderately suitable, $1.62 \%$ are marginally suitable, and $0.33 \%$ are not suitable. Followed by rainfall parameter, dry month, and slope produce the lowest suitability with $31.64 \%$ categorize as highly suitable, $9.17 \%$ are moderately suitable, $36.15 \%$ are marginally suitable, and $23.04 \%$ are classified as not suitable (Table 3 ).

According to altitude requirement, mostly all area in Bali Province have highly suitable for banana plants. Only in center of island where topography is dominated by mountains have moderately and marginally suitable, and small part area in Agung mountain area is classified as not suitable (Figure 3a). Based on rainfall requirement, almost all area categorized as highly suitable as well, just in north west part and in the center island classified as

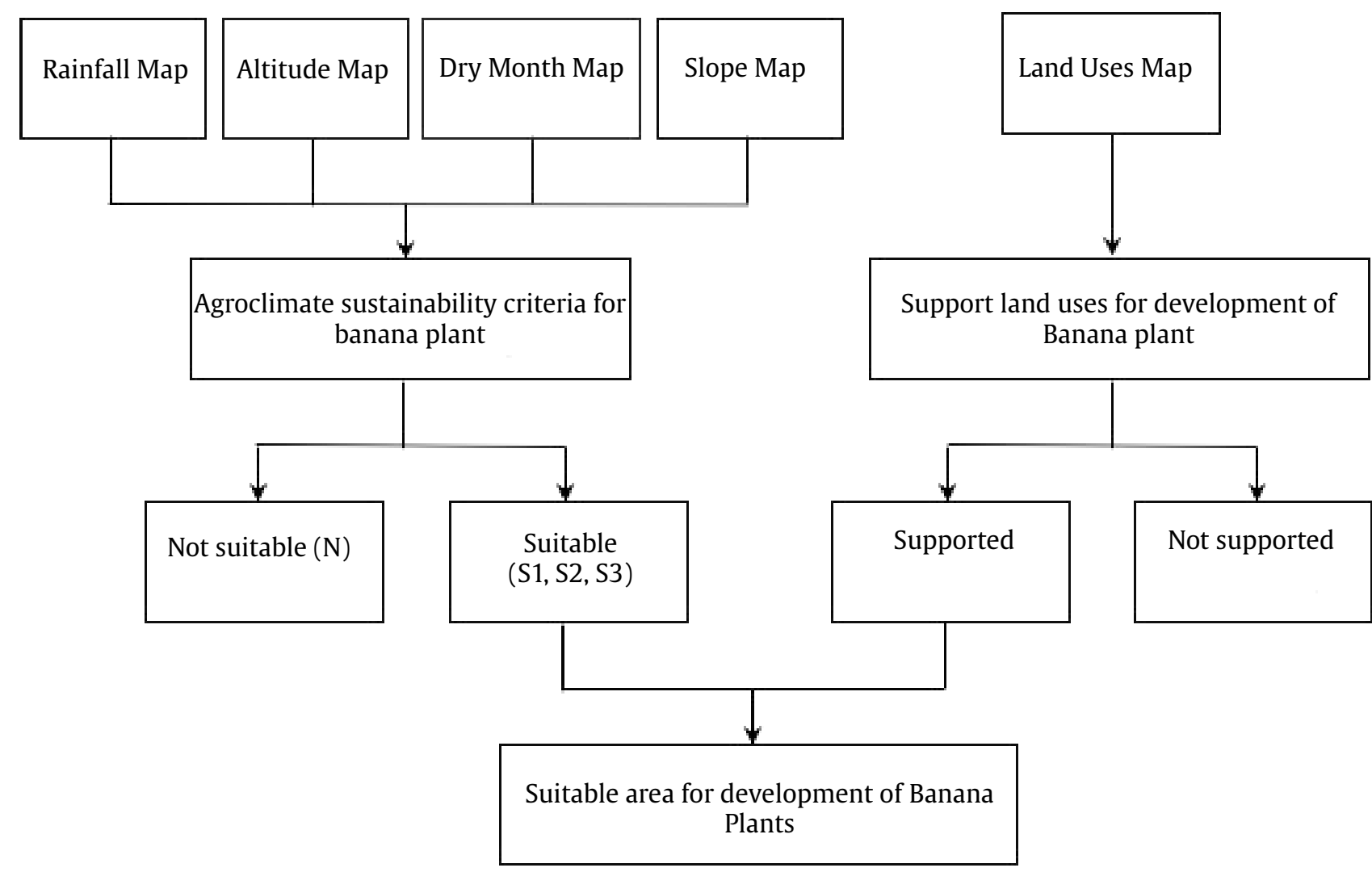

Figure 2. Flowchart of the research

Table 3. Percentage of land suitability for four agroclimate parameters

\begin{tabular}{lccrr}
\hline \multirow{2}{*}{ Land Suitability Class } & \multicolumn{4}{c}{ Percentage of Suitability } \\
\cline { 2 - 5 } & Altitude & Rainfall & Dry Month & Slope \\
\hline Highly suitable (S1) & 93.31 & 66.79 & 66.79 & 31.64 \\
Moderately suitable (S2) & 4.73 & 27.04 & 27.04 & 9.17 \\
Marginally suitable (S3) & 1.62 & 6.04 & 6.04 & 36.15 \\
Not suitable (N) & 0.33 & 0.12 & 0.12 & 23.04 \\
\hline & 100.00 & 100.00 & 100.00 & 100.00 \\
\hline
\end{tabular}


moderately and marginally suitable (Figure 3b). Dry month requirement shows that only in north part of Bali Province provides moderately and marginally suitable and most of rest classified as highly suitable (Figure 3c). Slope is the main limiting factor for development of banana plants. High slopes that classified as not suitable are found in the central part of the Bali island (Figure 3d).

\subsection{All Agroclimate Parameter Analysis of Banana Land Suitability}

Using all agroclimate parameters simultaneously produced more comprehensive result of land suitability analysis for banana plants. Based on map analysis using range value of suitability class in Table 1 shows that $21.45 \%$ of the study area classified as highly suitable (S1), $10.99 \%$ as moderately suitable (S2), $44.27 \%$ as marginally suitable, and 23.29 categorized as not suitable (Table 4).

Figure 4. shows that the not suitable class $(\mathrm{N})$ is found in the middle part of Bali island. This distribution pattern is similar with slope requirement (Figure 3d) because slope is the main limitation factor for development of banana plants.

\section{LAND SUITABLE MAP FOR BANANA PLANT IN BALI PROVINCE} Based on Altitude Requirements

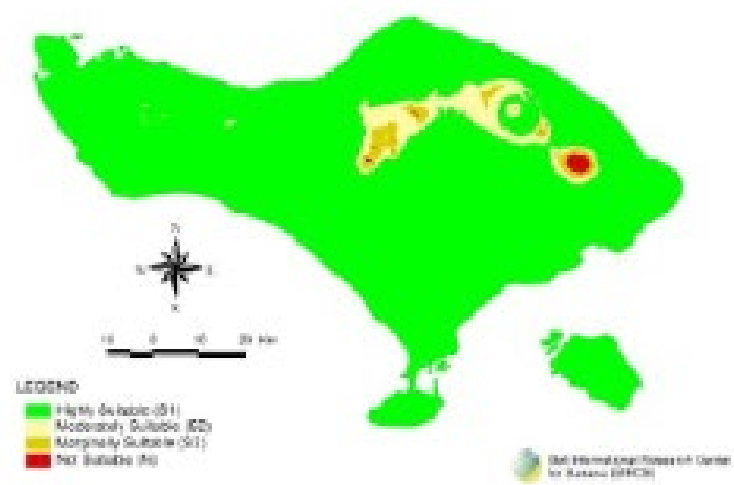

(a)

LAND SUITABLE MAP FOR BANANA PLANT IN BALI PROVINCE Based on Dry Month Requirements

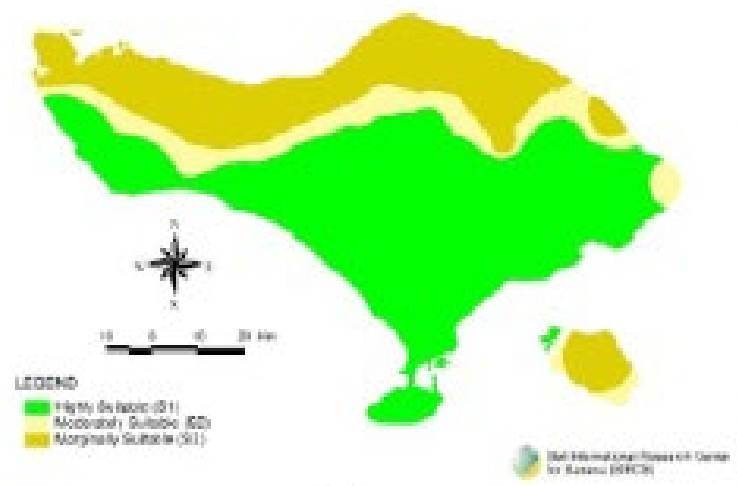

(c)

\subsection{Supporting Exiting Land Uses for Development of Banana Plants}

Although land suitable evaluation analysis produces suitable class for banana plants, it does not give a guarantee that this area can be used for development of banana plants. This is caused by not all the exiting land uses support for development of banana plants. Therefore, we need to decide the exiting land uses that can be used for banana plants base on Table 2. Figure $5 \mathrm{~b}$ shows that exiting land uses that support for developing of banana plants.

Table 4. Land suitable evaluation for Banana plants

\begin{tabular}{lrr}
\hline Suitability Class & Area (ha) & $\%$ \\
\hline Highly suitable (S1) & 119,617 & 21.45 \\
Moderately suitable (S2) & 61,302 & 10.99 \\
Marginally suitable (S3) & 246,906 & 44.27 \\
Not suitable (N) & 129,925 & 23.29 \\
\hline Total & 557,749 & 100.00 \\
\hline
\end{tabular}

According to exiting land uses, 329,012 ha (58.99\%) of study area is support for development of banana plants and 228,736 (41.01\%) does not support (Table 5 ). Red color in Figure $5 \mathrm{~b}$ indicates that it does not

\section{LAND SUITABLE MAP FOR BANANA PLANT IN BALI PROVINCE Based on Rainfall Requirements}

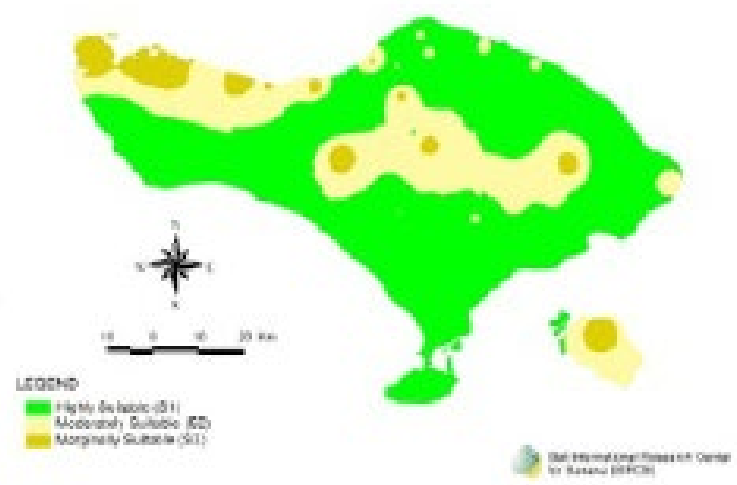

(b)

LAND SUITABLE MAP FOR BANANA PLANT IN BALI PROVINCE Based on Slope Requirements

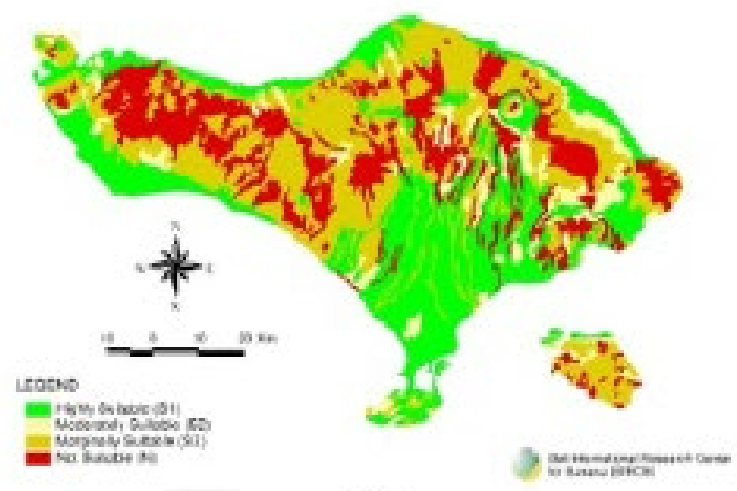

(d)

Figure 3. Land suitability map for four agroclimate parameters, (a) altitude, (b) rainfall , (c) dry month, and (d) slope 
LAND SUITABLE MAP FOR BANANA PLANT IN BALI PROVINCE Based on Agroclimate Requirements in Four Classes

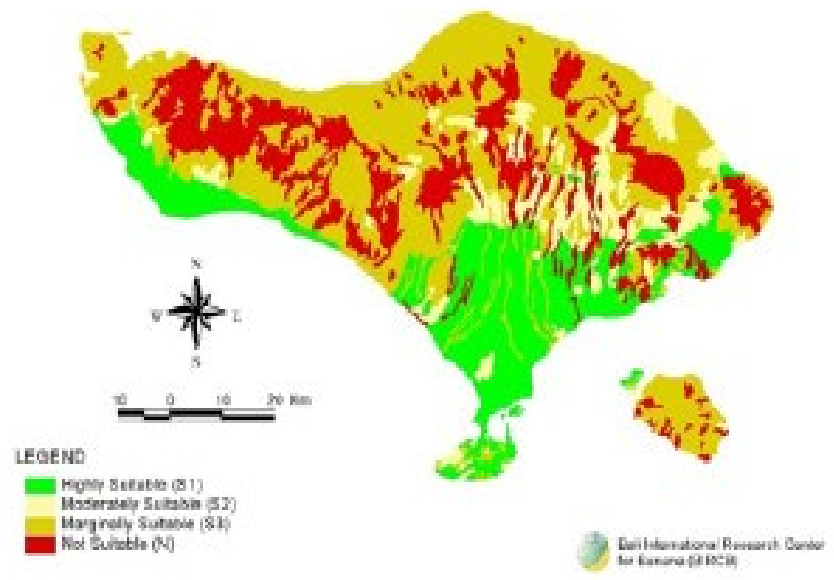

(a)
LAND SUITABLE MAP FOR BANANA PLANT IN BALI PROVINCE Based on Agroclimate Requirements in Two Classes

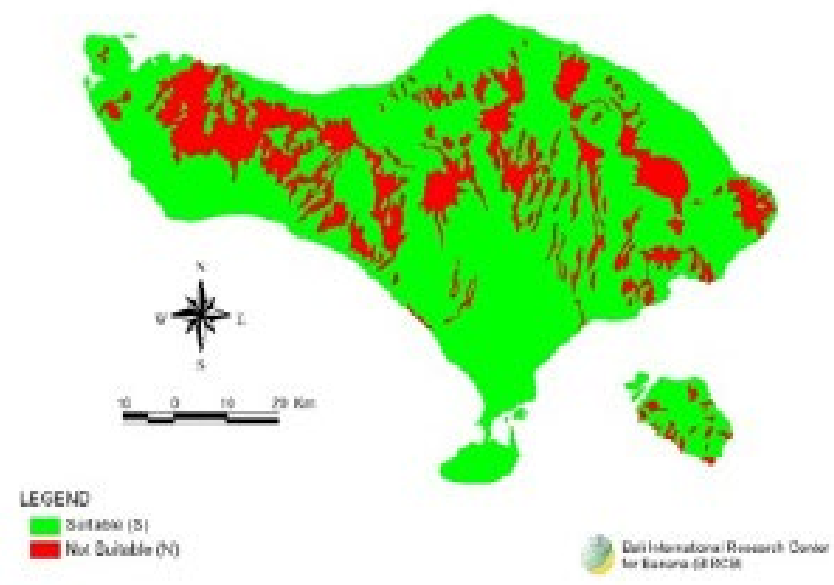

(b)

Figure 4. Map of land suitable evaluation for Banana plants, (a) four classes of land suitability, (b) two classes of land suitability

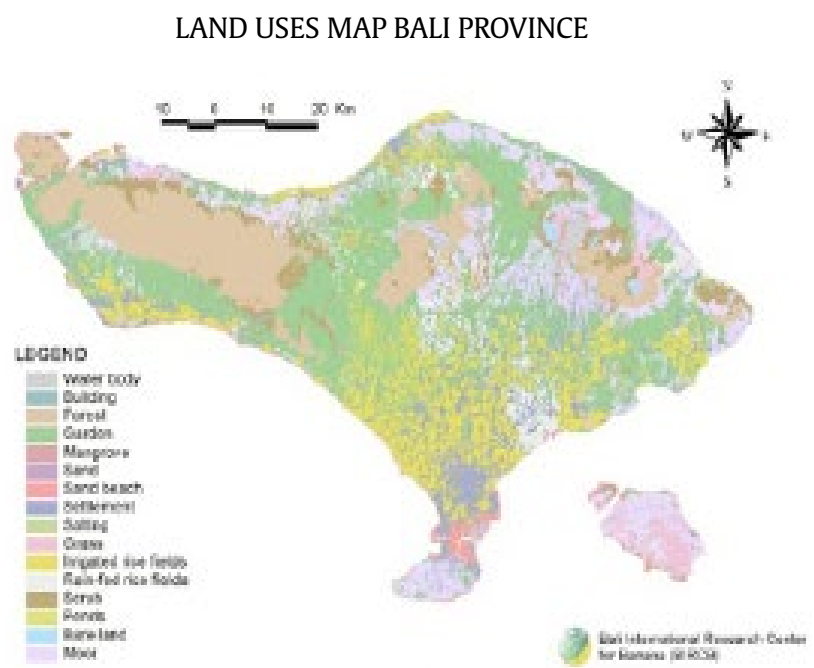

(a)
LAND SUITABLE MAP FOR BANANA PLANT IN BALI PROVINCE Based on Exiting Land Uses

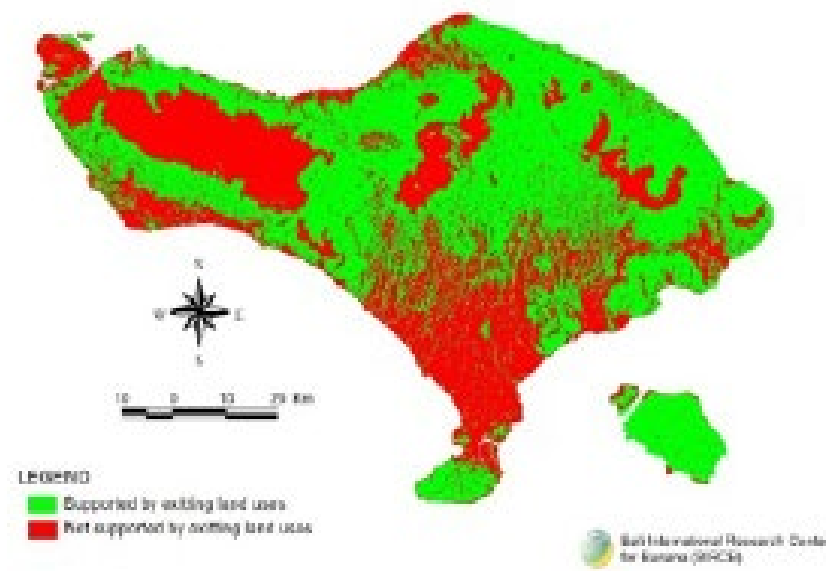

(b)

Figure 5. Exiting land uses that support for development of Banana plans, (a) exiting land uses and (b) supporting land uses for Banana plants.

suitable for development of banana plants and green color shows suitable area. The area that does not support for banana mostly found in forest and settlement land uses. It generally distributes in south and west part of Bali island, and only small part found in the middle and north part of Bali island.

Table 5. Supporting of exiting land uses for Banana plant

\begin{tabular}{lcr}
\hline Suitability Class & Area (ha) & $\%$ \\
\hline Support/suitable & 329,012 & 58.99 \\
Not support/not suitable & 228,736 & 41.01 \\
\hline Total & 557,749 & 100.00 \\
\hline
\end{tabular}

\subsection{Agroclimate Land Suitability and Exiting Land Uses Support for Development of Banana Plants}

The final analysis of this study is overlaying of agroclimate land suitability map and supporting exiting land uses as shown in flowchart (Figure 3). Four combination result of this analysis can be produced. As much as 257,467 ha $(46.16 \%)$ classified as agroclimately suitable $(\mathrm{S})$ and supported by exiting land uses, 169,837 ha (30.45\%) included agroclimately suitable (S) but does not supported by exiting land uses, 70,846 ha (12.07\%) categorized as agroclimately not suitable $(\mathrm{N})$ but supported by exiting land uses, and 59,598 ha (10.69\%) classified as agroclimately not suitable $(\mathrm{N})$ and does not supported by exiting land uses (Table 6). Spatial distribution of this area is presented in Figure 6.

\subsection{Final Suitability Area for Developing of Banana Plants}

Based on Table 6 and Figure 6, only the area classified as agroclimately suitable (S) and supported by exiting land uses can be utilized as an area for development of banana plants. In Figure 7, this area 
Table 6. Total area of agroclimate land suitability and exiting land uses support analysis

\begin{tabular}{lcc}
\hline Suitability Class & Area (ha) & $\%$ \\
\hline $\begin{array}{l}\text { Suitable agroclimate, supported by } \\
\text { land uses }\end{array}$ & 257,467 & 46.16 \\
$\begin{array}{l}\text { Suitable agroclimate, not supported } \\
\text { by land uses }\end{array}$ & 169,837 & 30.45 \\
$\begin{array}{l}\text { Not suitable agroclimate, supported } \\
\text { by land uses }\end{array}$ & 70,846 & 12.70 \\
$\begin{array}{l}\text { Not suitable agroclimate, not } \\
\text { supported by land uses }\end{array}$ & 59,598 & 10.69 \\
\hline Total & 557,749 & 100.00 \\
\hline
\end{tabular}

LAND SUITABLE MAP FOR BANANA PLANT IN BALI PROVINCE Based on Agroclimate Requirements and Land Uses Support

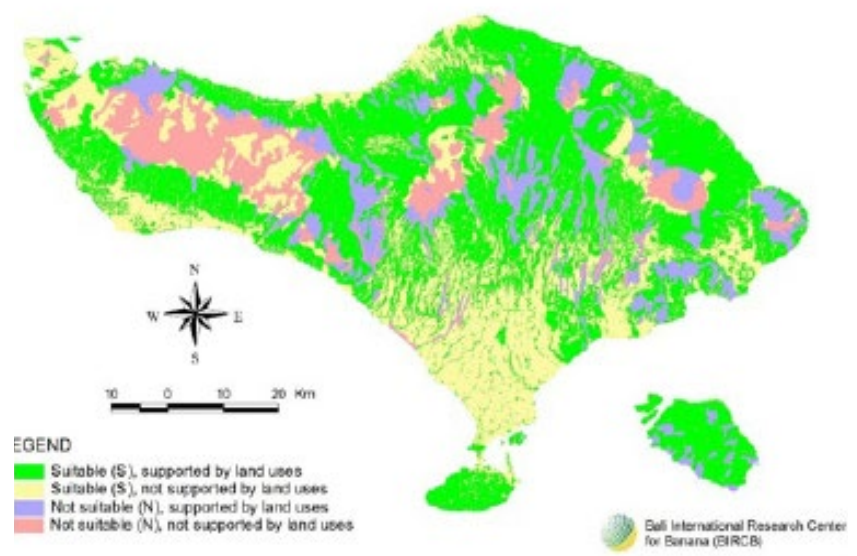

Figure 6. Map of land suitable for banana plants based on agroclimate requirement and supporting exiting land uses

is shown as green color with the total area is about 257,467 ha (46.16\%) from Bali Province. The land that can be used for development of banana plants is spread almost evenly throughout the Bali Province.

Buleleng Regency has the widest area for developing banana plants about 65,313 ha or $25.37 \%$ from total suitable area. Followed by Karangasem, Tabanan, Jembrana and Bangli with the area of 45,337 (17.61\%), 35,292 (13.71\%), 30.365 ha (11.79\%), and $29,909(11.62 \%)$ respectively. Denpasar town has the smallest suitable area for developing banana plants, that is 944 ha $(0.37 \%)$ (Table 7$)$.

\section{Discussion}

Slopes are the most severe limiting factor of agroclimate in the development of banana plants, while the altitude, rainfall and dry months is not a limiting factor in the development of bananas. Current land use may also be a limiting factor in the development of banana plants. Not all types of existing land use can be used for the development of Banana plant. Types of currently land use that are not recommended for the development of crops are settlements, forests, rice fields.

Based on statistic data from Central Bureau of Statistics (BPS 2016), Bangli Regency has the highest annual average production of banana last five years,
Table 7. Development area for Banana Plants by regency

\begin{tabular}{lrcr}
\hline Regency & Suitable (ha) & Not Suitable (ha) & \% Suitable \\
\hline Badung & 15,289 & 22,697 & 5.94 \\
Bangli & 29,909 & 22,827 & 11.62 \\
Buleleng & 65,313 & 65,043 & 25.37 \\
Gianyar & 15,383 & 20,604 & 5.97 \\
Jembrana & 30,365 & 54,620 & 11.79 \\
Karangasem & 45,337 & 38,903 & 17.61 \\
Klungkung & 19,633 & 11,557 & 7.63 \\
Tabanan & 35,294 & 52,186 & 13.71 \\
Denpasar & 944 & 11,055 & 0.37 \\
\hline Bali Province & 257,467 & 299,491 & 100.00 \\
\hline
\end{tabular}

\section{DEVELOPMENT AREA MAP FOR BANANA PLANTS IN PROVINCE} BALI

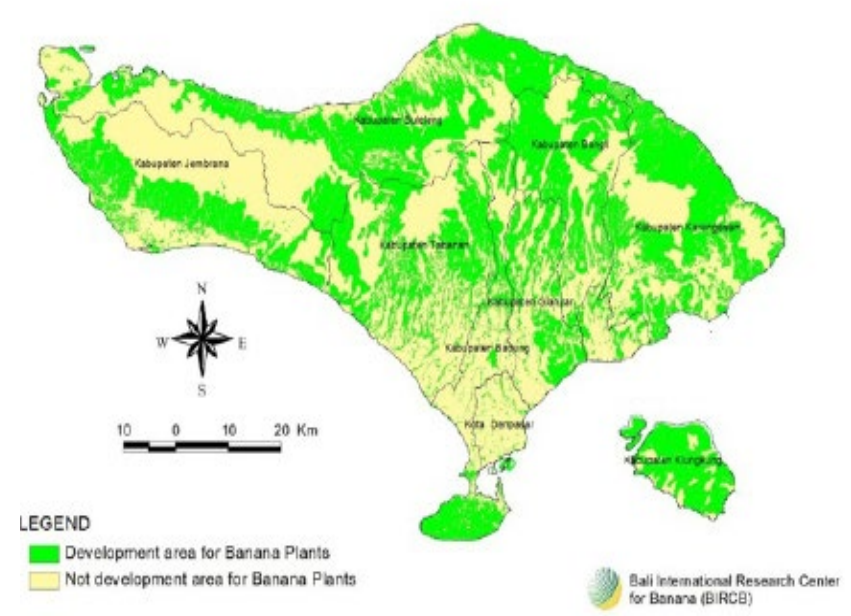

Figure 7. Final map of land suitable for banana plants

that is about 100,438 ton or $52.80 \%$ of total banana production in Bali Province. Followed by Jembrana and Buleleng regency with the average production of 23,450 ton (12.33\%) and 22,515 ton (11.84\%) respectively. Denpasar town has the lowest average production of 222 ton $(0.12 \%)$.

Bali Province has a high potential for the development of banana plants that is 257,467 ha, $46.16 \%$ of the province of Bali. This means that the potential of land for development of banana plants in Bali Province has not been developed optimally. Buleleng Regency has the widest area for the development of banana plants, followed by Karangasem, Tabanan, Jembrana and Bangli. Denpasar town has the smallest suitable area.

In the first stage, maximizing the utilization of suitable land for the development of banana plants, banana needs of the Bali people can be met without bringing from outside the region. The next stage, with the increasing number and quality of banana production, Bali Province has opportunity to export bananas out of the region and also abroad.

\section{References}

[BPS] Badan Pusat Statistik 2016. Bali Province in Figures 2016. Central Bureau of Statistics. 
Djaenudin D et al. 2003. Land Evaluation Technical Guide for Agricultural Commodities. Soil Research Institute. Soil Research and Development Center. Bogor Agency for Agricultural Research and Development. pp. 154.

Elsheik AR et al. 2010. An agricultural investment map based on geographic information system and multi-criteria method. J Appl Sci 10:1596-1602.

[FAO] Food and Agriculture Organization 2007. Land Evaluation Towards a Revised Framework. Food and Agriculture Organization of the United Nations, Rome, Italy.

[FAO] Food and Agriculture Organization 2014. FAO urges countries to step up action against destructive banana disease. Food and Agriculture Organization of the United Nation.

Giardini L et al. 1997. Laclassificazione agronomica del territorio: proposta metodologica del sistema CAT II. GenioRurale. 5, pp. 53-64.

He Y et al. 2011. Regional Land Suitability Assessment for Tree Crops Using Remote Sensing and GIS. Computer Distributed Changsha Control and Intelligent Environmental Monitoring (CDCIEM) IEEE. pp. 354363.

Kamkar B et al. 2014. Assessment of land suitability and the possibility and performance of a canola (Brassica napus L.) - soybean (Glycine max L.) rotation in four basins of Golestan province, Iran. The EJRS 17: 95104.
Malczewski J. 2004. GIS-based land-use suitability analysis: a critical overview. Progress in Planning 62: 3-65.

Martin D, Saha S K, 2009. Land evaluation by integrating remote sensing and GIS for cropping system analysis in a watershed. Cur Sci 96: 569-575.

Mu Y, 2006. Developing a Suitability Index for Residential Land Use: A Case Study in Dianchi Drainage Area. Canada, University of Waterloo. Malczewski J, 2004. GIS-based land-use suitability analysis: a critical overview. Progress in Planning. 62: 3-65.

Pan G, Pan J, 2012. Research in crop land suitability analysis based on GIS. CCTA 365: 314-325.

Perveen $\mathrm{F}$ et al. 2007. Crop land suitability analysis using a multicriteria evaluation and GIS approach, $5^{\text {th }}$ International Symposium on Digital Earth. Berkeley The University of California, USA. pp. 1-8.

Samanta S et al. 2011. Land Suitability Analysis for Rice Cultivation Based on Multi-Criteria Decision Approach through GIS Int J Sci Emerging Tech 2: 12-20.

Sonneveld MPW et al. 2010. Thirty years of systematic land evaluation in the Netherlands. Geoderma 156: 84-92. 